\title{
Hot shower therapy in cannabinoid hyperemesis syndrome: A case report
}

\author{
Kannabinoid hiperemezis sendromunda sıcak duş tedavisi: Bir olgu sunumu
}

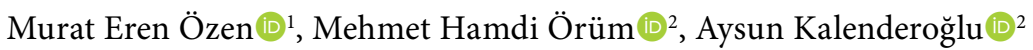 \\ ${ }^{1}$ Department of Psychiatry, Private Adana Hospital, Adana, Turkey \\ ${ }^{2}$ Department of Psychiatry, Adryaman University Faculty of Medicine, Adryaman, Turkey
}

\begin{abstract}
Cannabis is one of the most widely used addictive substances. Abuse of this drug is associated with various long- and short-term adverse effects. Dizziness, shallow breathing, red eyes and dilated pupils, dry mouth, increased appetite, and slowed reaction time are a few effects of cannabis. It can be used as an antiemetic and for the treatment of cachexia in cancer patients. A paradoxical clinical phenomenon called cannabinoid hyperemesis syndrome (CHS) is also reported. Cannabinoid hyperemesis syndrome is characterized by recurrent episodes of intractable nausea and vomiting in patients using cannabis daily for years. Patients with CHS benefit compulsively from hot water since it relieves symptoms. The possible mechanism is skin vasodilation. This article aims to show the effectiveness of hot shower treatment in cases with cannabinoid hyperemesis. To our knowledge, this is the first case to address hot shower therapy in the treatment of CHS in Turkey.
\end{abstract}

Keywords: Cannabinoid hyperemesis syndrome; cannabis; hot shower treatment; male.

\section{öz}

Esrar, en çok kullanılan bağımlıık yapıcı maddelerden biridir. Bu ilacın kötüye kullanımı çeşitli uzun ve kısa süreli olumsuz etkiler ile ilişkilidir. Baş dönmesi, sığ solunum, kırmızı gözler ve dilate pupiller, ağız kuruluğu, iştah artışı ve reaksiyon süresinin yavaşlaması esrar etkilerinden bazılarıdır. Antiemetik olarak ve kanser hastalarında kaşeksi tedavisinde kullanılabilir. Kannabinoid hiperemezis sendromu (KHS) olarak adlandırılan bir paradoksik klinik fenomen de bildirilmektedir. Kannabinoid hiperemezis sendromu, yıllardır günlük olarak esrar kullanan hastalarda inatçı bulantı ve kusma ile karakterizedir. Kannabinoid hiperemezis sendromlu hastalar semptomları hafiflettiği için dürtüsel olarak sıcak sudan faydalanırlar. Olası mekanizma cilt vazodilatasyonudur. Bu yazıda, kanabinoid hiperemezisli olgularda sıcak duş tedavisinin etkinliği gösterildi. Bildiğimiz kadarıyla bu olgu Türkiye'de KHS tedavisinde sıcak duş tedavisini ele alan ilk olgudur.

Anahtar sözcükler: Kannabinoid hiperemezis sendromu; esrar; sıcak duş tedavisi; erkek.

The active substance in cannabis is 9-tetrahydrocannabinol (THC). Cannabis is a common name for cannabis sativa biologically active substances and can be used for all preparations made from Indian cannabis, among which are the best-known marijuana and hashish. Marijuana is a preparation made from dried parts of the plant, and hashish from the Indian hemp resin. Cannabis use may cause euphoria, relaxation, increased socialization and more intense perception, while sensory disturbances and depersonalization may also occur. The consequences of the use of THC were shown as memory disorders, learning disturbances (ability to learn) as well as amotivation syndrome (apathy, intrusion of intersex). Particularly in 
vulnerable people, cannabis use can even trigger psychotic disorders. For medical purposes, it is used as an antiemetic and for the treatment of cachexia in cancer patients and acquired immune deficiency syndrome (AIDS). In addition to the many known adverse effects of cannabis in recent years, a paradoxical clinical phenomenon called cannabinoid hyperemesis syndrome (CHS) is also reported. ${ }^{[1]}$ In this article, we discuss the symptomatology and efficacy of hot shower therapy in the treatment of CHS for the first time in a Turkish patient.

\section{CASE REPORT}

In August 2017, a 23-year-old male patient applied to our emergency service due to vomiting and epigastric pain that began on the day of the examination. The patient was afebrile and had normal blood pressure, heart rate, and saturation of arterial blood. The abdomen was soft, tinged pain in the epigastric region, but without typically enlarged organs or pathological resistances. Laboratory work-ups (hemogram, C-reactive protein, electrolytes, urea, creatinine, amylase, lipase and hepatic tests) did not show any deviations from the normal values. A written informed consent was obtained from the patient.

In his medical history, he was examined repeatedly by surgeons and gastroenterologists in the recent years due to similar symptomatology. He was evaluated firstly in 2014 after an ambulatory endoscopic approach for pain in the stomach and vomiting and was prescribed esomeprazole. In 2015, he was re-examined for the same problems; gastroscopy revealed mild reddening of stomach and bulb of the duodenum without other changes in the mucous membrane. In 2016, he was accepted by the internal medicine of our hospital due to repeated vomiting, abdominal pain, and severe psychomotor impairment. Ultrasound examination of the abdomen did not show any peculiarities, and the urine screening test confirmed the presence of THC. The patient acknowledged that he smoked marijuana and discontinued treatment of a psychiatrist. Based on past data, a toxicological urine test was repeated and the presence of THC in the urine was shown repeatedly. In a conversation with the patient, we confirmed that the problems with vomiting and upper abdominal pain actually occur after smoking marijuana. He was smoking daily for nearly three years, but rarely until 2015 . The duration of the problems was parallel with his daily marijuana consumption. According to the symptomatology and medical history, patient was diagnosed as CHS with high probability. In the treatment of his emergent state, he was taken to a hot shower, which relieved his symptoms and decreased his abdominal pain and vomiting. He was advised to stop smoking marijuana, and in the case of reuse and occurrence of problems, shower with hot water.

\section{DISCUSSION}

Cannabinoid hyperemesis syndrome was first described in 2004 in Australia, when Allen et al. ${ }^{[2]}$ identified the correlation between cannabis use and repeated vomiting and abdominal pain in nine patients. The hectic effect of cannabis is paradoxical, as numerous articles published in the last decade confirm the antiemetic and analgesic effect of cannabis in chronic patients and cancer patients on chemotherapy. ${ }^{[3-5]}$ The mechanisms of cannabis effect are not fully explained. They are probably the result of stimulation of cannabinoid receptors in the brain.

The paradoxical emetic effect is explained by the long half-life of cannabis, its liposolubility and effect on the gastrointestinal tract, as it slows down the gastric emptying and reduces peristalsis. The effect on the gastrointestinal tract in sensitive chronic cannabis users could result in the accumulation of lipophilic THC over the central anti-emetic effect, causing vomiting and cramping abdominal pain. ${ }^{[6,7]}$ Unfortunately, we did not have precise data on how much marijuana our case had already consumed. Weakness and vomiting are also the adverse effects of acute consumption of marijuana, not just chronic. In addition, nausea and vomiting may also occur within the abstinence syndrome after sudden discontinuation of marijuana use. ${ }^{[8]}$ It is also interesting to note that patients with CHS often benefit compulsively from hot water, as long as it relieves/eases symptoms. It is possible that in this way, the induced vasodilation in the skin redirects the flow of 
blood from the gastrointestinal tract and thus reduces the symptoms, while this can only be the direct action of $\mathrm{THC}$ on the cannabinoid receptors (CB1) receptor in the hypothalamus and its thermoregulatory centre. ${ }^{[6,9]}$ The medial over optic part of the hypothalamus is primarily a thermosensitive region in central nervous system, which is very rich in $\mathrm{CB} 1$ cannabinoid receptors. In addition, it is known that in animals, hypothermia can be induced by lowering body temperature by giving greater doses of endocannabinoids. ${ }^{[10]}$ In our patient, compulsive hot water showering behavior was not observed as seen in the literature. ${ }^{[9,10]}$

Patients are advised to shower with hot water to relieve the symptoms of cannabinoid hyperemesis, and in the long run, quit using cannabis for effective results. Studies conclude that while symptoms of patients who stop using cannabis are relieved, they reappear after reuse. ${ }^{[7,9]}$

In recent years, more and more synthetic cannabinoids have been used -for example, in the so-called "spice" preparations-. Smokers of synthetic cannabinoids also have problems such as nausea and vomiting. Unfortunately, synthetic cannabinoids cannot be confirmed by immunological urine tests. In the event of a suspicion of misuse of synthetic cannabinoids, a urine test should be carried out on a gas chromatography device with a mass detector.

Differential diagnosis should be considered for $\mathrm{CHS}$ as a consequence of smoking cannabis, particularly in young patients with unexplained repeated vomiting. In such cases, it should be acceptable/appropriate to conduct a rapid test for the presence of psychoactive substances in the urine, particularly for metabolites of THC. No doubt, the first treatment procedure is abandonment of the causative; here, withdrawing from THC use.

\section{Declaration of conflicting interests}

The authors declared no conflicts of interest with respect to the authorship and/or publication of this article.

\section{Funding}

The authors received no financial support for the research and/or authorship of this article.

\section{REFERENCES}

1. Voth EA, Schwartz RH. Medicinal applications of delta-9-tetrahydrocannabinol and marijuana. Ann Intern Med 1997;126:791-8.

2. Allen $\mathrm{JH}$, de Moore GM, Heddle R, Twartz JC. Cannabinoid hyperemesis: cyclical hyperemesis in association with chronic cannabis abuse. Gut 2004;53:1566-70.

3. Tramèr MR, Carroll D, Campbell FA, Reynolds DJ, Moore RA, McQuay HJ. Cannabinoids for control of chemotherapy induced nausea and vomiting: quantitative systematic review. BMJ 2001;323:16-21.

4. Wang T, Collet JP, Shapiro S, Ware MA. Adverse effects of medical cannabinoids: a systematic review. CMAJ 2008;178:1669-78.

5. Darmani NA, Crim JL. Delta-9-tetrahydrocannabinol differentially suppresses emesis versus enhanced locomotor activity produced by chemically diverse dopamine D2/D3 receptor agonists in the least shrew (Cryptotis parva). Pharmacol Biochem Behav 2005;80:35-44.

6. Sontineni SP, Chaudhary S, Sontineni V, Lanspa SJ. Cannabinoid hyperemesis syndrome: clinical diagnosis of an underrecognised manifestation of chronic cannabis abuse. World J Gastroenterol 2009;15:1264-6.

7. Patterson DA, Smith E, Monahan M, Medvecz A, Hagerty B, Krijger L, et al. Cannabinoid hyperemesis and compulsive bathing: a case series and paradoxical pathophysiological explanation. J Am Board Fam Med 2010;23:790-3.

8. Stempelj M, Ferjan I. Kanabinoidi - njihovo delovanje in ucinki. Farm Vestn 2006;57:30-3.

9. Chang YH, Windish DM. Cannabinoid hyperemesis relieved by compulsive bathing. Mayo Clin Proc 2009;84:76-8.

10. Darmani NA. Cannabinoid-Induced Hyperemesis: A Conundrum-From Clinical Recognition to Basic Science Mechanisms. Pharmaceuticals (Basel) 2010;3:2163-2177. 